\title{
О ДВОЙНОМ КАУЗАТИВЕ В ДАРГИНСКИХ ЯЗЫКАХ
}

\section{ABOUT DOUBLE CAUSATIVES IN DARGIN LANGUAGES}

\section{R. Mutalov}

Summary: The article deals with the formation and functioning of double causatives in Dargin languages. This issue has not previously been the object of special research in the sphere of Dargin languages study. The main attention in the article is paid to the methods of grammatical formation of single causative in Dargin idioms, and to the methods of double causatives formation. It has been established that double causatives are formed by adding derivative - $\mathrm{axb}$ to the analytical forms of the causative. The results of this research can be helpful to the study of double causatives in other related languages and in typological research.

Keywords: caucasian languages, Dargin languages, morphology, grammatical categories, increasing derivation, causative, actant changes.

\author{
Муталов Расул Османович \\ Д.филол.н., профессор, г.н.с., Институт языкознания \\ Российской академии наук (2. Москва), \\ mutalovr@mail.ru
}

Аннотация: В статье рассматриваются вопросы образования и функционирования двойных каузативов в даргинских языках. Данная проблема в даргиноведении ранее не становилась объектом специального исследования. Основное внимание в статье уделено способам грамматического оформления в одинарного каузатива даргинских идиомах, а также механизму образования двойных каузативов. Установлено, что двойные каузативы образуются присоединением к аналитическим формам каузатива дериватемы -ахъ. Результаты работы могут быть применены при изучении двойных каузативов в других родственных языках и типологических исследованиях.

Ключевые слова: кавказские языки, даргинские языки, морфология, грамматические категории, повышающая деривация, каузатив, актантные изменения.
马

аргинские языки (нахско-дагестанская семья языков) распространены в Центральном Дагестане. Традиционно они считались диалектами даргинва, но в последние десятилетия, вследствие имеющихся между ними значительных расхождений, рассматриваются в качестве самостоятельных языков, что является вполне обоснованным [4]. Различия проявляются на всех языковых уровнях, в том числе, на лексическом и грамматическом. Данный факт подтверждается также результатами, полученными в ходе настоящего исследования, посвященного характеристике каузативных конструкций в рассматриваемых языках. Каузатив является своего рода узловой категорией, в которую вовлечены морфология, синтаксис, лексика и семантика.

Каузатив, как правило, «стремится выражать наиболее общее и наиболее неопределенное значение, допускающее в различных прагматических контекстах целый ряд интерпретаций - быть причиной, заставить, приказать, настоять, пригласить, предложить, попросить, разрешить, дать и т.п.» [7, с. 390].

Каузативы относится к средствам повышения актантной деривации в языке. Различают каузативы морфологический, лексический и синтаксический. Морфологический каузатив характеризуется наличием в языке регулярного морфологического процесса образования маркированных каузативных глаголов от немаркированных. Синтаксические каузативы представляют собой аналитические конструкции, образованные посредством вспомогательных глаголов, выражающих смысл каузации. При лексическом каузативе компонент «кау- зировать» инкорпорирован в семантическую структуру глаголов.

Каузативная деривация является чрезвычайно продуктивным и распространенным явлением в даргинских языках. Она привлекала к себе внимание даргиноведов всегда, начиная с работы П.К. Услара [11]. Каузативы и каузативные конструкции, как правило, рассматриваются в научных грамматиках и обобщающих трудах [1, 3, 6], имеется лишь 2 специальные статьи, посвященные даргинскому каузативу $[5,9]$. Основное внимание в этих исследованиях уделяется морфологическим характеристикам каузативов и актантным изменениям, происходящих при канонических каузациях в разных даргинских идиомах. Между тем, обнаруживается, что многие явления даргинских каузативных конструкций, представляющие собой типологический интерес, остаются пока неисследованными.

В образовании каузативных форм в даргинских языках можно выделить 2 этапа: это образование одинарного каузатива, и от него - двойного. Одинарный каузатив представляет собой грамматическую форму, которая содержит один из показателей каузатива - каузативную морфему -ахъ или полувспомогательные каузативные глаголы -барес «сделать», -аэс «превратить». Присоединением каузативной дериватемы -ахъ образуются синтетические формы, а полувспомогательные глаголы служат для образования аналитических каузативов.

Синтетический, или морфологический, каузатив занимает особое место в словообразовательной системе 
даргинских языков - данная форма может быть образована практически от любого глагола. Показателем каузатива акушинского (основы даргинского литературного языка) и большинства других языков служит дериватема -ахъ-, которая присоединяется непосредственно к гла-

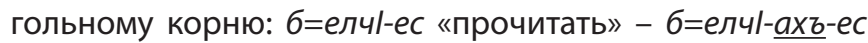
«заставить прочитать».

При наличии в слове фарингализации гласный $a$ дериватемы -ахъ переходит в гласный более нижнего подъема я, в результате чего образуется вариант -яхъ: букьес «пойти», букь+ахъес - букь-яхъ-ес «заставить пойти». В форме глагола белх1-ехъ-ес «разбудить», образованной от глагола белх1ес «проснуться» каузативная морфема содержит гласный $е$.

Каузативная дериватема -ахъ- имеет привилегированное положение в структуре глагола - она присоединяется непосредственно к корневому согласному, вклиниваясь между ним и другими посткорневыми морфемами: барг-ахъ-ес «заставить найти». При этом все другие элементы словоформы, функционирующие до процесса каузации непосредственно за корневым согласным (показатели претерита, маркеры императива и оптатива, личные окончания хабитуалиса, показатели вербоидов, формативы и т.д.), перемещаются в постпозицию.

Суффикс -ахъ- присоединяется как к основе совершенного, так и к основе несовершенного вида: бицlaхъес «заставить наполнить, наполнить» - бириlaxъес «заставлять наполнять; наполнять». Данная морфема может сохраняться и при образовании всех других словоизменительных и словообразовательных парадигм глагола.

Довольно интересный случай представляет собой явление морфологического выражения каузатива в непереходных формах глагола северных даргинских языков. Непереходная форма 3-го лица при присоединении показателя каузатива становится переходной: в=uрul-ap «наполнится (он)»- в=ирul-aхъ-у «наполнят (его)». В формах 1-го и 2-го лиц появляются личные показателя -pa, -pu:

1л. ну в=uрul-ус «я наполнюсь» - ну в=upul-axъ-y-pa «меня наполнят»,

2л. xly в=uрul-уд «ты наполнишься» - xly в=upulахъ-у-ри «тебя наполнят».

1л. Ну ля=в=Кь-яС «я приду» $-u m-u-н и$ ну ля=в=Кьяхъ-у-ра «он заставит меня прийти»;

2л. Xly ля=в=кь-яд «ты придешь» - um-u-ни xly ля=в=кb-яхъ-y-pu «он заставит тебя прийти».

По все видимости, в данном случае происходит двойная маркировка лица, в результате чего выпадают элементы с, д глагольного личного показателя:

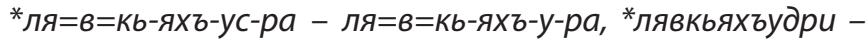
лявкьяхъури. Явление двойной маркировки лица извест- но и в других формах северных языков; личные показатели -pa, -pu наслаиваются на другие личные показатели -ус, -уд: б=ир-ис-ра «сделаю».

Дериватема -ахъ не может присоединяться к формам немаркированного оптатива (*вuцlaхъ (ср. вицl «пусть заполниться»)) и к непереходным формам императива (*кайахъи (при кайи «садись»)). Не присоединяется также данная морфема к формам настоящего времени глагола б=иэс «быть» (са=й «есть», ахlен «не является», ле=в «имеется», аг-ар-а» не имеется»).

Даргинский глагол диг-ахъ-ес «любить» функционирует в форме хабитуалиса только с морфемой каузатива: Наб учlес дигахъис «я люблю учиться» (хабитуалис); ср.: наб учlес дигулра «я хочу учиться» (презенс). Т.е., данный глагол совмещает значения «хотеть» и «любить». В хабитуалисе функционирование данного глагола возможно только в значении «любить», а в презенсе - в значении «хотеть».

П. Услар, впервые обративший внимание на даргинский каузатив, пишет, что показателем каузатива в урахинском языке является глагол ихъис «преодолевать»: «Понудительный залог образуется постоянно через присоединение к глагольному корню окончания ихъис». В показателе каузатива данного идиома «наряду с

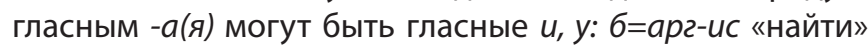

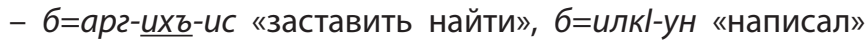
- б=илкl-ухб-ун «заставил написать»» [11, с. 204], т.е. наблюдается дистанционная регрессивная ассимиляция гласных - гласный маркера претерита уподобляет гласный суффикса каузатива. Услар полагает, что показатель каузатива в урахинском языке восходит к глаголу ихъис «преодолевать» [11, с. 204].

В кайтагском и ицаринском языках заднеязычные корневые согласные перед показателем каузатива переходят в переднеязычные согласные: бугарай «оставаться»- бужахъуй. Подобное явление в других случаях в ицаринском отмечается лишь в позиции перед гласны-

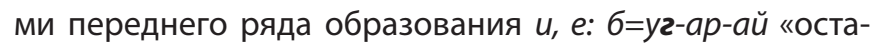
ваться» - б=уж-иб (имперфект).

В ряде даргинских языков - кубачинском, чирагском, кункинском, синтетический каузатив отсутствует; каузативные конструкции образуются аналитическим путем - присоединением того или иного вспомогательного глагола к инфинитиву. Считается, что вспомогательный глагол в этих диалектах не успел морфологизироваться $[2$, c. 58].

А. Магометов отмечает, что в кубачинском языке образование каузативных форм различается в зависимости от глагольного вида - совершенного или несовершенного вида: «Каузативные формы в кубачинском 
образуются при помощи глагола ахъий «преодолеть» (в недлительном виде), ихъий (в длительном виде). При образовании каузативной формы в глаголах недлительного вида изменение претерпевает спрягаемый глагол: он утрачивает суффиксальную часть, и к основе, оканчивающейся на корневой согласный, присоединяется глагол ахъий в полной форме: бахьв-ахъий (от бахьвий-ахъий) «заставить засеять»; ср.: бахьвий «засеять», ахъий «преодолеть», бисахъий «заставить продать», от бисий «продать». В глаголах длительного вида спрягаемый глагол сохраняет форму инфинитива, вспомогательный глагол, присоединяясь к форме инфинитива, утрачивает начальный гласный и: балхьвий-хъий (от балхьвий-ихъий) «заставить сеять»» [6, с. 214].

Показателем каузатива чирагского диалекта выступает глагол бацlе-бяхъи «растапливать» [3, с. 78]; ср. акуш.: баulaxъec «pacmonumb».

Аналитические каузативы в даргинских языках образуются присоединением вспомогательных глаголов барес, аэс, в семантике которых содержится значение каузации, к разным основам. Следует отметить, что ранее в даргиноведческой литературе об этом виде образования каузативов не упоминалось.

Можно выделить 3 типа основ, к которым могут присоединиться вспомогательные глаголы со встроенным каузативным значением: это именные основы, причастие общее и инфинитив НСВ. Нужно отметить, что к любой из этих основ может присоединяться также неагентивный вспомогательный глагол биэс «стать», образуя стативные глаголы, которые являются непереходными. Таким образом, при этом создаются каузативные пары. Как отмечает В.А. Плунгян, «различия между стативными и динамическими глаголами многообразны; главным среди них является, пожалуй, то, что для продолжения состояния обычно не требуется никаких специальных усилий субъекта; не требуется притока энергии для его поддержания. Именно поэтому субъектом состояния чаще является пациенс или экспериенцер... Динамические ситуации обозначают либо различные виды изменений, либо, по крайней мере, такие состояния, для поддержания которых требуется постоянный приток энергии (и субъектом которых является агенс)» [10, с. 246].

Основанием для того, чтобы рассматривать полученные формы в качестве каузативов, служат 2 факта: а) имеется грамматический показатель -полувспомогательный глагол барес / аэс, выражаюий значение каузации; б) в полученной конструкции появляется новый агенс в эргативе.

Исходная ситуация при этом необязательно должна выступать в виде завершенного предложения, это может быть и подситуация, выражающая какую-нибудь дан- ность, которая подвергается каузации. Например: и1акь «сила» (исходная данность» - ц1акьбарес - «усилить, сделать сильным».

Присоединение вспомогательных глаголов к именной основе рассматривается как способ образования сложных глаголов. Вспомогательные глаголы с семантикой каузации могут присоединяться также к двум отглагольным образованиям: это причастие общее и инфинитив НСВ. При этом следует отметить, что причастие общего времени по своим характеристикам близко к именным основам; аналитические формы также данные формы образуют аналогично: посредством присоединения глагола -барес «сделать».

Аналитический каузатив от инфинитива образуется посредством присоединения вспомогательного глагола аъес «превратить, заставить»: бузесаэс «заставить работать».

В южнодаргинских языках в глаголе $а$ аъ-ес сохранился увулярный спирант гъ, который в северных языках, в частности, в акушинском имеет соответствие ъ (смычку) $а$ б-ес - агъ-уй Можно допустить, что корень -агъ данного слова может лежать в основе образования каузативной дериватемы-aхъ, распространенной в даргинских языках.

Образование стативных глаголов от основы инфинитива происходит посредством вспомогательного глагола биэс (б=uъ-ес). Данный глагол является омонимичным другому вспомогательному глаголу биъэс, который образует стативные глаголы от именных основ и причастия общего. Эти два глагола отличаются также в южнодаргинских языках: глаголу биъэс соответствует глагол биигарай «начало становления какого-либо состояния» с долгой гласной основы. В работе [6] данные формы рассмотрены в качестве элементов парадигмы категории фазовости, которые передают значение «начало действия или состояния».

В даргинских языках возможны также двойные каузативы. Они образуются присоединением к аналитическим формам каузатива дериватемы -aхъ. Следует отметить, то суффикс - ахъ может присоединяться и к некаузативному элементу каузативной пары.

Каузативы от сложного глагола с именной основой:

(m1уm1у-дарес «рассыпать» - m1уm1у-дикес «рассыпаться»): Анк1и т1ут1удикиб «зерно рассыпалось» (некаузативное значение, стативный глагол) - Итини анк1u m1ут1удикахъиб «он (ненамеренно) рассыпал зерно» (морфологический каузатив, пермиссивное значение, контактный, слабый) - Итини анк1и m1уm1удариб «он (намеренно) рассыпал зерно» (аналитический каузатив, фактитивное значение, контактный, сильный) - Мурадли итизи анк1и т1ут1ударахъиб «Мурад заставил его рас- 
сыпать зерно» (двойной каузатив, фактитивное значение, дистантный, сильный).

Каузативы от причастия общего времени:

Урши вашаниуб «мальчик стал ходить» (некаузативный глагол) - Тухтурли урши вашаниахъуб «врач помог мальчику, и тот стал ходить» (морфологический каузатив). - Тухтурли урши вашанвариб «врач сделал так, что мальчик стал ходить» (аналитический каузатив) - Ибрагьимли тухтурлизи урши вашанварахъиб «Ибрагим воздействовал на врача, и врач способствовал тому, что мальчик стал ходить» (двойной каузатив).

Каузативы от инфинитива НСВ:

Сяг1ят бузесбииб «часы стали работать» - Устали ся21ят бузесбиахъиб «мастер починил часы (заставил работать)» (морфологический каузатив) - Устали сяг1ят бузесаиб «мастер сделал так, что часы стали работать» (аналитический каузатив) - Каримли устализи сяг 1 ят бузесаахъиб «Карим воздействовал на мастера с тем, чтобы тот починил часы, и часы стали работать» (двойной каузатив).

Из примеров видно, что при присоединении к имен- ным основам каузативной дериватемы -ахъ к вспомогательным глаголам со стативным значением новый агенс, как правило, имеет пермиссивное значение, действие протекает помимо его воли. Между тем, подобное явление не наблюдается в двух других случаях каузации. Каузация вербоидов (причастия общего и инфинитива HCB) отличается от каузации сложных глаголов с именными основами тем, что в них при маркировке каузатива морфологическим показателем -ахъ невозможно пермиссивное значение, т.е. невозможны значения с ненамеренным агенсом:

Тухтурли урши вашаниахъуб «врач ( ${ }^{*}$ нечаянно) помог мальчику, и тот стал ходить» (морфологический каузатив). Устали сяг 1 ят бузесбиахъиб «мастер ( ${ }^{*}$ нечаянно) починил часы (заставил работать)»

Таким образом, в даргинских языках представлена широкая система образования каузативных конструкций, которые относятся к средствам повышения актантной деривации в языке. Возможны как одинарные каузативы, образованные синтетическим или аналитическим путем, так и двойные каузативы, которые оформляются дериватемой -ахъ, присоединяемой к одинарным каузативным формам.

\section{ЛИТЕРАТУРА}

1. Абдуллаев С.Н. Грамматика даргинского языка (фонетика и морфология). Махачкала, 1954. 218 с.

2. Ганенков Д.С. Реконструкция эволюции конъюнктива в даргинских языках // Acta Linguistica Petropolitana. Труды института лингвистических исследований. 2016. Т. 12. № 1. С. 53-64.

3. Кибрик А.Е., Кодзасов С.В. Сопоставительное изучение дагестанских языков. Глагол. М., 1988. 225 с.

4. Коряков Ю.Б.. Атлас кавказских языков. М.: Пилигрим, 2006. 57 с.

5. Магометов А.А. Каузатив в лакско-даргинской группе дагестанских языков // ЕИКЯ. Т. 4. Тбилиси, 1977. С. 172-187.

6. Магометов А.А. Кубачинский язык. Исследование и тексты. Тбилиси, 1963. 342 с.

7. Мельчук И.А. Курс общей морфологии. Том.ІІ. М., 1998. 544 с.

8. Муталов 20030 морфологическом каузативе в даргинском языке // Вестник ДГУ. Вып. Х. Махачкала, 2003. С. 89-96.

9. Муталов Р.О. Глагол даргинсого языка. Махачкала: ИПЦ ДГУ, 2002. 216 с.

10. Плунгян В.А. Общая морфология. Ведение в проблематику. М., 2000. 384 с.

11. Услар П.К.. Этнография Кавказа. Языкознание. Т. 5. Хюркилинский язык. Тифлис, 1892.503 с.

() Муталов Расул Османович (mutalovr@mail.ru). 